\title{
Assessment of Depression Impact on Runoff Characteristics Using GIS Technique
}

\author{
Morad Abdelsalheen, Ashraf M. Elmoustafa, Ahmed A. A. Hassan
}

\begin{abstract}
Depression is a storage volume that could be filled prior to runoff. It might be used as a rectification parameter to adjust runoff volumes and peak discharges. GIS tools are used to extract depressions and calculate their characteristics (volume - area) and to pick the corresponding catchments and estimate their characteristics from DEM. In this work, HEC-HMS is used as a step to calculate runoff using three approaches to assess the impact of presence of depressions on runoff from three points of view; outlet location, runoff volume and peak discharge downstream the depression. First approach neglects the presence of depression. Second approach accounts depression in study but assuming one outlet with width equal to one cell size and lastly the third approach is as same as second approach but multi outlets are used with different widths and levels. The last approach gives more realistic value for runoff volume and peak discharge as it accounts volume of water stored in depression and represents the outflow from depression in an accurate way.
\end{abstract}

Index Terms - GIS, Depression, HEC-HMS, Routing, Runoff.

\section{INTRODUCTION}

Rainfall and runoff processes can be studied either by physical or numerical model [1]. Runoff passing through a reservoir is attenuated as it can be temporarily stored during storms in the reservoir or depression to mitigate downstream flooding. The continuity and momentum equations are applied to investigate runoff propagation through a reservoir [2]. Furthermore, Routing techniques are used to deduce surface runoff hydrographs. Selection of runoff routing method is effective as it related to the nature of Up-stream watershed characteristics and required accuracy. Also, routing is classified as hydrologic and hydraulic. For Hydrologic models, they have a closed form of solution equation, while hydraulic models need numerical integration with a finite difference approach [3]. HEC-HMS is used for calculating the runoff volume and peak discharge resulting from catchments and reservoirs using different techniques of hydrological modeling and routing.

\section{METHODOLOGY}

In the present study, a Hydrologic Modeling System (HEC-HMS) was used to calculate runoff volumes and peak discharges by simulating the precipitation - runoff processes

Morad Abdelsalheen, Irrigation \& Hydraulics Department, Ain Shams University/ Faculty of Engineering, Cairo, Egypt, 00201005537026

Ashraf M. Elmoustafa, Irrigation \& Hydraulics Department, Ain Shams University/ Faculty of Engineering, Cairo, Egypt, 00201005198385

Ahmed A. A. Hassan, Irrigation \& Hydraulics Department, Ain Shams University/ Faculty of Engineering, Cairo, Egypt, 00201003359907 of drainage catchments through applying the Soil Conservation Service SCS methodology equations. While the attenuation caused by depressions was simulated through applying Outflow structures routing by presenting the depression as a reservoir and its outlet as long-crested spillway.

Reservoir within HEC-HMS are not simulated to receive precipitation so a pseudo sub-basin with the same top surface area of depression is used to simulate direct rainfall into depression (lag time $=$ minimum)[4]. And the outflow from retention with horizontal water surface can be computed with level-pool routing which discretizes time into equal intervals of duration $(\Delta t)$. one-dimensional approximation of continuity equation can be used to simulate routing.

$$
I_{\text {avg }}-O_{\text {avg }}=\frac{\Delta S}{\Delta t}
$$

Where, $\mathrm{I}_{\text {avg }}$ and $\mathrm{O}_{\text {avg }}$ are average inflow and outflow during time interval; $\Delta \mathrm{S}$ is storage change during the same duration, with finite difference approximation, equation (1) can be written as:

$$
\frac{I_{t}+I_{t+1}}{2}-\frac{o_{t}+O_{t+1}}{2}=\frac{s_{t+1}-S_{t}}{\Delta t}
$$

Where, $t$ is index of time interval; $I_{t}$ and $I_{t+1}$ are inflow values at the beginning and end of the $\mathrm{t}^{\text {th }}$ time interval respectively; and $\mathrm{O}_{\mathrm{t}}$ and $\mathrm{O}_{\mathrm{t}+1}$ are corresponding outflow values; and $S_{t}$ and $S_{t+1}$ are corresponding storage values[5].

Outflow structures routing method is used in this model, as it accounts for reservoirs with number of uncontrolled outlet structures. Automatic adaption of time step selection method was used to get possible precision in the results[6]. Outlets were chosen as spillway to simulate overflow of water from depression and a long-crested spillway is selected as a type of spillway.

In Equation 4, for long crested weir, by increasing crest length coefficient of weir decrease[7]. Thus, $\mathrm{C}$ was taken with a minimum value (1.10) from the recommended HEC-HMS range (1.10 to 1.66$)$.

$$
\begin{aligned}
& \mathrm{Q}=\mathrm{C} * \mathrm{~B} *(\mathrm{H})^{2 / 3} \\
& \mathrm{C}=3\left(\frac{\mathrm{H}}{\mathrm{L}}\right)^{0.022}
\end{aligned}
$$

In this study, three approaches were used to evaluate the effect of depression geometry and outlet characteristics on runoff volume and peak discharge. In first approach, catchments were defined by intersecting between drainage lines and outer perimeter of depression but depression was treated as a catchment area, Figure 1. Likewise, in second and third approaches, the corresponding catchments were calculated as same as first approach. Table 1 Illustrates catchments' morphological parameters for different approaches. 


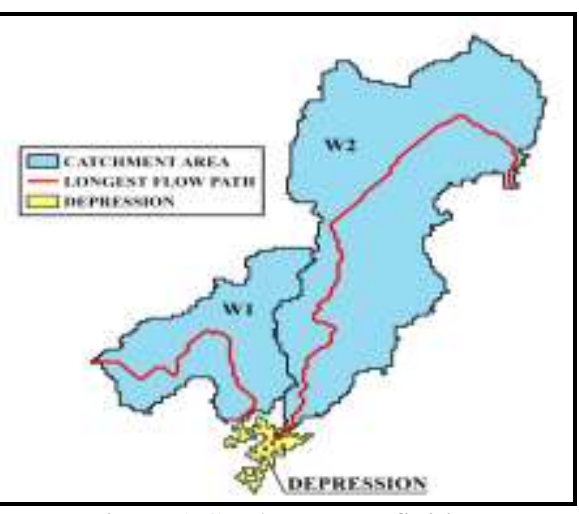

Figure 1 Catchments Definition

Table 1 Catchments' Morphological Parameters

\begin{tabular}{|c|c|c|c|c|c|}
\hline $\begin{array}{c}\text { Catchment } \\
\text { Name }\end{array}$ & $\begin{array}{c}\text { Catchment } \\
\text { Area } \\
\left(\mathbf{K m}^{2}\right)\end{array}$ & $\begin{array}{c}\text { Longest } \\
\text { flow path } \\
(\mathbf{m})\end{array}$ & $\begin{array}{c}\mathbf{C N} \\
\text { assumed }\end{array}$ & $\begin{array}{c}\mathbf{T}_{\mathbf{C}} \\
(\mathbf{m i n})\end{array}$ & $\begin{array}{c}\mathbf{T}_{\text {Lag }} \\
(\mathbf{m i n})\end{array}$ \\
\hline W1 & 16.52 & 8308 & 75 & 396 & 238 \\
\hline W2 & 46.02 & 17261 & 75 & 606 & 364 \\
\hline DEPRESSION & 1.57 & 2485 & 75 & 202 & 121 \\
\hline
\end{tabular}

\section{A. First Approach}

In this approach, as most of morphological models incorrectly do. Runoff generated from catchments was calculated assuming no depression effect was considered. The total depression surface area was considered and treated as a catchment area free from depressions and a semi-distributed model (HEC-HMS) was used to calculate runoff volume and peak discharge at an outlet point (junction) downstream the depression. In this approach, assuming the Drainage lines will continue in their direction. Peak discharge and runoff volume were calculated at a collection point (junction) downstream the depression accounting the corresponding catchments and also depression area as a catchment. Figure 2 .

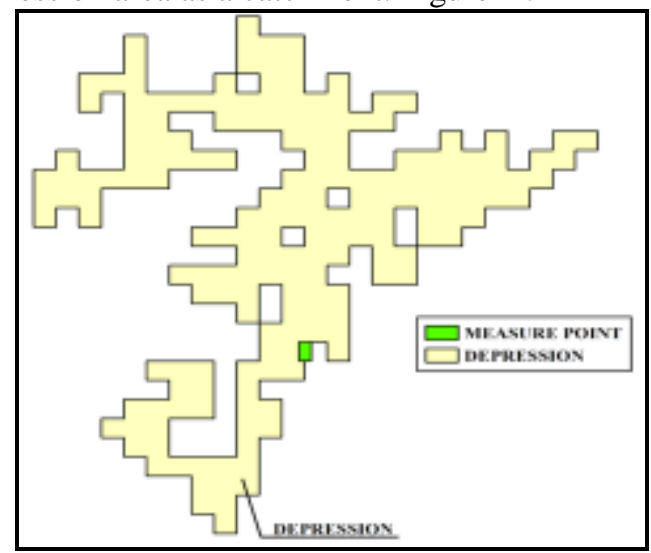

Figure 2 Peak Discharge and Runoff Volume Measuring Locations ( $1^{\text {st }}$ Approach)

However, in second and third approaches, the outlet were defined as lowest point/points in the depression perimeter.

\section{B. Second Approach}

In this approach, the depression effect was considered, the runoff from catchments and intercepted precipitation by depression were used to fill out depression volume then overflowed from one outlet (lowest one) which is the outlet point considered in the first approach. HEC-HMS was also used to calculate runoff volume and peak discharge of excess flow from depression assuming the outlet as one long-crested spillway with crest width equal to one cell size. The outlet location was defined as a spillway with crest width equal to one cell size. Which was located at one of lowest parts of depression perimeter. Figure 3

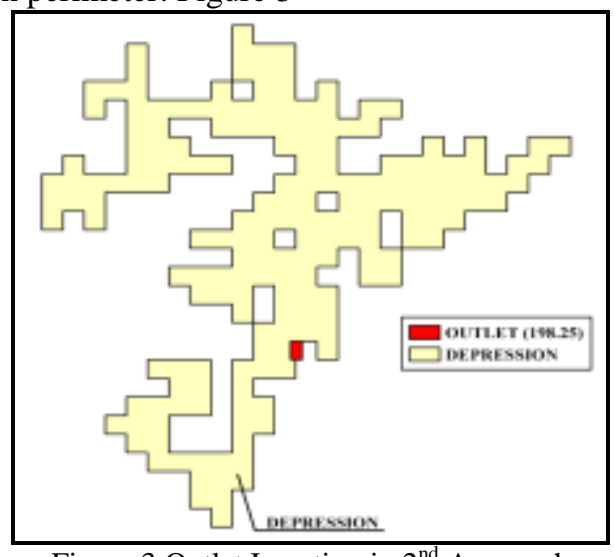

\section{Third Approach}

Similarly, in this approach, the depression effect was also considered yet using a more realistic simulation of outlet points. The runoff from catchments and intercepted precipitation by depression were used to fill out the depression volume then overflowed from multi outlets (lowest points along the perimeter). HEC-HMS was also used to calculate runoff volume and peak discharge of excess flow from depression assuming the outlets as long-crested spillways with different crest widths and levels. The outlets locations were defined as a multilabel spillways with different crest widths and levels. Which were located at the lowest parts of depression perimeter. Figure 4.

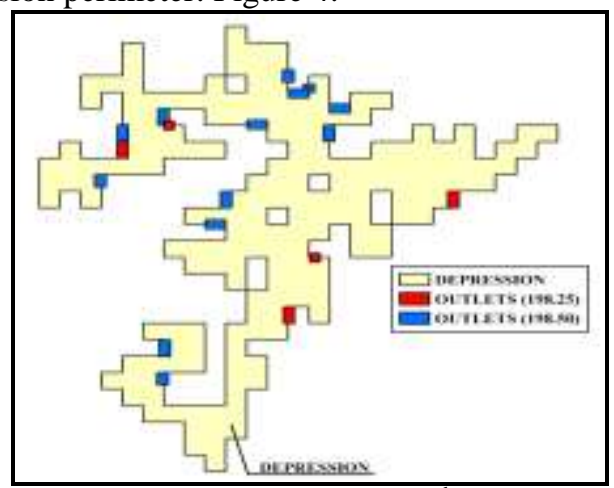

Figure 4 Outlets Locations in $3^{\text {rd }}$ Approach

\section{DEPRESSION MORPHOLOGICAL CHARACTERISTICS}

\section{A. Perimeter Profile}

Using ARC-GIS, extracting crest widths and levels is accomplished by defining depression first, then generating a profile for the depression perimeter, Figure 5, Finally grouping crests with same level. Table 2 shows the crest width at each level of outer perimeter of depression.

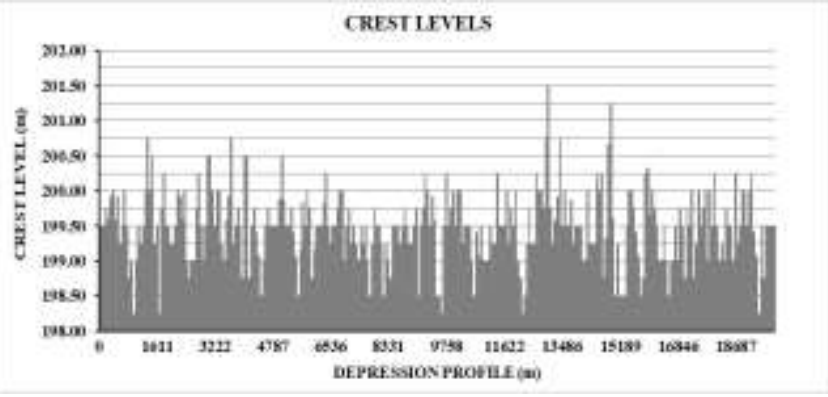

Figure 5 Depression Perimeter Profile 
Table 2 Length at each level of Outer perimeter of Depression

\begin{tabular}{|c|c|}
\hline Elevation $(\mathrm{m})$ & Length $(\mathrm{m})$ \\
\hline 198.25 & 368 \\
\hline 198.50 & 1066 \\
\hline 198.75 & 852 \\
\hline 199.00 & 1995 \\
\hline 199.25 & 2470 \\
\hline 199.50 & 5224 \\
\hline 199.75 & 1757 \\
\hline 200.00 & 2186 \\
\hline 200.25 & 805 \\
\hline 200.50 & 483 \\
\hline 200.75 & 245 \\
\hline 201.00 & 0 \\
\hline 201.25 & 69 \\
\hline 201.50 & 92 \\
\hline Total Length & $17612 \mathrm{~m}$ \\
\hline
\end{tabular}

\section{B. Volume Rating Curve and Surface Area}

Figure 6 was also developed using GIS tools which show Volume Rating Curve and Surface Area for the depression at each level. The morphological parameter for depression can be summarized as follow:

- Total Length of Outer Perimeter $=17,612 \mathrm{~m}$.

- Top Surface Area $=1,567,745 \mathrm{~m}^{2}$

- Total Volume $=4,732,894 \mathrm{~m} 3$

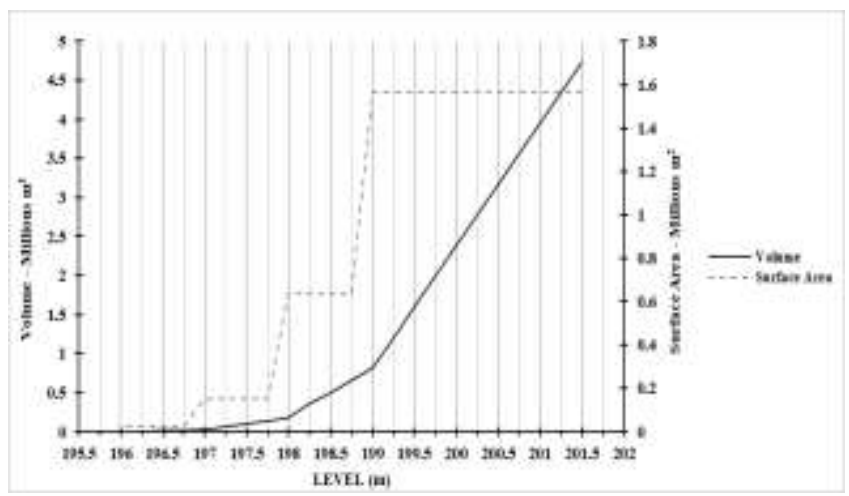

Figure 6 Volume Rating Curve and Surface area for Depression

\section{STORM DESCRIPTION}

A hypothetical storm was used in the study with a depth of $150 \mathrm{~mm}$ which was applied as a uniform storm on the area of the depression and its corresponding catchments. This value was selected by trials in order to operate multi spillways with different crest heights. A Soil Conservation service (SCS-II) storm method implemented as a design storm pattern which was applied on all sub-basins (catchments /depression).

\section{RESULTS}

\section{A. Runoff Volume}

To evaluate the effect of depression (reservoirs), Storage Ratio (SR) was used which attained with dividing the stored volume by the total volume of inflow at the reservoir. Positively, the higher values of these indices are, the greater efficiency is of reservoirs in detention[8].

For second and third approaches, computed runoff volume composed of the volume of water calculated at outlets (Spillways) after subtracting the depression storage.
Conversely, for first approach the depression effect in neglected.

Table 3 Runoff Volumes for three approaches

\begin{tabular}{|c|c|c|c|c|}
\hline Approach & $\begin{array}{c}\text { Calculated } \\
\text { Inflow } \\
\text { volume } \\
\left(1000 \mathbf{~ m}^{3}\right) \\
\end{array}$ & $\begin{array}{c}\text { Calculated } \\
\text { Outflow } \\
\text { volume } \\
\left(1000 \mathbf{~ m}^{3}\right) \\
\end{array}$ & $\begin{array}{l}\text { Volume } \\
\text { stored } \\
\left(1000 \mathbf{~ m}^{3}\right)\end{array}$ & SR (\%) \\
\hline First & \multirow{3}{*}{5236.26} & 5236.26 & 0.00 & -- \\
\hline Second & & 4869.40 & 366.86 & 7.00 \\
\hline Third & & 4868.40 & 367.86 & 7.03 \\
\hline
\end{tabular}

In Table 3, It is obviously noted that for second and third approaches have almost the same percentage of (SR) with a minute difference about $0.03 \%$ between two approaches due to difference in outlets configurations (Spillways).

\section{B. Peak Discharge}

The values of peak discharge reduction depend on the level up to which a reservoir is filled[9]. In this study, depression was assumed to be empty before the storm. Flood Attenuation Ratio (FAR) is defined as the ratio of discharge reduction in the reservoir (difference between the maximum input and output dis charges) to the input peak discharge in the reservoir[8]. And was used to compare between the three approaches.

Table 4 Peak Discharge for three approaches

\begin{tabular}{|c|c|c|c|c|c|}
\hline Approach & $\begin{array}{c}\text { Peak } \\
\text { Inflow } \\
\left(\mathrm{m}^{3} / \mathrm{sec}\right)\end{array}$ & $\begin{array}{c}\text { Peak } \\
\text { Outflow } \\
\left(\mathrm{m}^{3} / \mathrm{sec}\right)\end{array}$ & $\begin{array}{c}\text { Difference } \\
\left(\mathbf{m}^{3} / \mathbf{s e c}\right)\end{array}$ & $\begin{array}{c}\text { Peak } \\
\text { water } \\
\text { level } \\
(\mathbf{m})\end{array}$ & $\begin{array}{c}\text { FAR } \\
(\%)\end{array}$ \\
\hline First & \multirow{3}{*}{139.48} & 126.45 & 13.03 & -- & 10.30 \\
\hline Second & & 139.04 & 0.44 & 198.62 & 0.32 \\
\hline Third & & 113.06 & 26.42 & 199.33 & 18.94 \\
\hline
\end{tabular}

In Table 4, It is clearly seen that there is a great difference in FAR between second and third approaches and this was due to difference in outlets configuration (Spillways). Also, water was stored in second and third approaches to level $198.62 \mathrm{~m}$ and $199.33 \mathrm{~m}$ respectively. And this was a result for when a one outlet was used, water was stored to higher level until discharged. But for multi-outlets water was stored to level $0.71 \mathrm{~m}$ lower than third approach. For the first approach, peak outflow was a middle value between first and second approaches not because of depression but due to longest flow path characteristics.

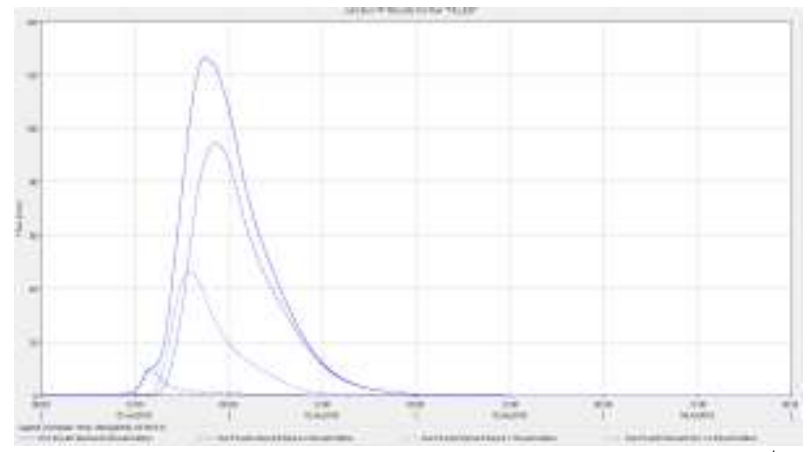

Figure 7 Storage, water elevation and flow versus time for $1^{\text {st }}$ Approach

Figure 7 shows the runoff discharge from each catchment (W1, W2 and Depression as a catchment) and the cumulative discharge from all catchment. And maximum runoff discharge was $126.45 \mathrm{~m}^{3} / \mathrm{sec}$. 


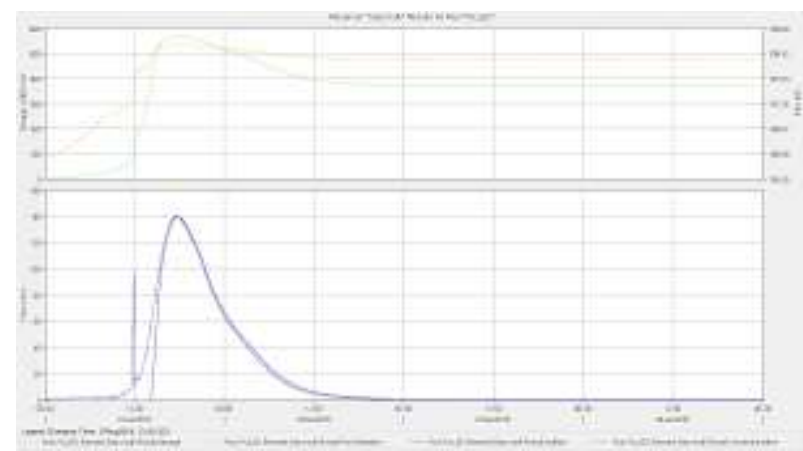

Figure 8 Storage, water elevation and flow versus time for $2^{\text {nd }}$ Approach

For the second approach, Figure 8 reveals two graphs. The first graph shows storage in $1000 \mathrm{~m}^{3}$ and water level with time. And second graph also shows the peak discharge with time. The storage, water level and peak discharge were $367860 \mathrm{~m}^{3}$, $199.33 \mathrm{~m}$ and $113.06 \mathrm{~m}^{3} / \mathrm{sec}$ respectively.

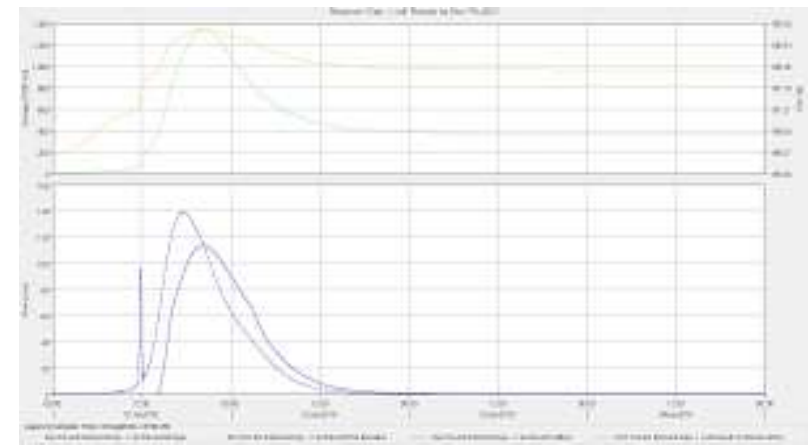

Figure 9 flow versus time for 3rd approach

Similarly, for the third approach, Figure 9, The storage, water level and peak discharge were $366860 \mathrm{~m}^{3}, 198.62 \mathrm{~m}$ and $139.04 \mathrm{~m}^{3} / \mathrm{sec}$ respectively.

\section{CONCLUSIONS}

Outflow volume is depending on depression characteristics and doesn't affected with the configuration of spillway. and peak discharge affected with the configuration of spillway.

From the previous results, three approaches were conducted, the first one which most hydrological models adopt, assumes no depression exists. And this is inaccurate assumption in calculating runoff volume as it gets the highest value of outflow volume as no water stored in a depression. For the second approach, one outlet was used and it is also not a real approximation but it can be used as an approach in calculating outflow volume but not in a conservative way. In third approach, which is most real one, As when water fills the depression volume and start to flood out from depression, it floods from different outlets hence, the resulting water level in this approach is lower than second one and leading to the most conservative values of peak outflow. Also, it gives a non-conservative but more realistic value for runoff volume as a portion of water is stored in depression.

\section{REFERENCES}

[1] Guo, J., Storm-Water Predictions by Dimensionless Unit Hydrograph. Journal of Irrigation and Drainage Engineering, 2006. 132(4): p. 410-417.

[2] Garcia- Navarro, P. and V. Zorraquino, Numerical Modeling of Flood Propagation through System of Reservoirs. Journal of Hydraulic Engineering, 1993. 119(3): p. 380-389.

[3] Akram, F., et al., Comparison of Different Hydrograph Routing Techniques in XPSTORM Modelling Software: A Case Study.
International Journal of Environmental and Ecological Engineering, 2014. 8(3): p. 213-223.

[4] Sterling, E.A. and C. Schoenfelder, Lake Samish Comprehensive Stormwater Plan - Hydrologic Modeling - Summary of Results and Recommendation. 2010.

[5] Feldman, A.D., Hydrologic Modeling System HEC-HMS (Technical Reference Manual). 2000

[6] Scharffenberg, W., Hydrologic Modeling System HEC-HMS (User's Manual). 2016.

[7] RAO, N.S.G. and D. MURALIDHAR, Discharge characteristics of weirs of finite-crest width. La Houille Blanche, 1963: p. 537-545.

[8] Kaboosi, K. and R. Jelini, The efficiency of detention reservoirs for flood control on the Jafar Abad River in Golestan province (Iran). Russian Meteorology and Hydrology, 2017. 42(2): p. 129-134.

[9] LEE, K.T., C.-H. CHANG, and M.-S. YANG, Reservoir attenuation of floods from ungauged basins. Hydrological Sciences-Journal-des Sciences Hydrologiques, 2001. 46(3): p. 349-362.

Morad Abdelsalheen received the B.S. and M.S. degrees in Civil Engineering from Faculty of Engineering, Ain Shams University in 2008 and 2014, respectively. During 2008-2018, he worked as a Teaching Assistant in Faculty of Engineering, Ain Shams University. He Also worked as a civil engineer at Engineering Consultancy Unit - Ain Shams University and a part-time civil engineer at different Consultancy offices.

Dr. Ashraf M. Elmoustaf, works as a professor at the Irrigation and Hydraulics Department, Faculty of Engineering, Ain Shams University. His work focuses on the Hydrology, hydro-informatics, River Engineering, and GIS application in water engineering.

He teaches a few water related topics (i.e. Engineering Hydrology, Dam Engineering, Irrigation and Drainage Engineering, and others) for both graduate and post graduate classes.

His research varies between water related branches; he had published several manuscripts in related peer reviewed journals through his work and post graduate studies under his supervision. He is also a reviewer for specialized journals in the field. Among these researches, water resources management, flood control and inundation studies the storm-water management in arid environment, hydrologic and hydraulic studies/analysis Dr. Ashraf has participated and is now involved in multinational projects with academic infinities in Germany, Turkey, USA, Jordan, Netherlands and many African countries.

Dr. Ahmed A. A. Hassan, works as a professor at the Irrigation and Hydraulics Department, Faculty of Engineering, Ain Shams University. His work focuses on the Environmental Hydrology, River Engineering, and GIS application in water resources engineering.

He teaches a few water related topics (i.e. Environmental Hydrology, Irrigation and Drainage Engineering, and others) for both graduate and post graduate classes.

His research varies between water related branches; he had published several manuscripts in related peer reviewed journals through his work and post graduate studies under his supervision. He is also a reviewer for specialized journals in the field.

Dr. Ahmed has participated and is now involved in multinational projects with academic infinities in Germany and many African countries. 